\title{
Comparison of methacholine and mannitol challenges: importance of method of methacholine inhalation
}

\author{
Donald W. Cockcroft ${ }^{1,2^{*}}$, Beth E. Davis ${ }^{1}$ and Christianne M. Blais ${ }^{1}$
}

\begin{abstract}
Background: Direct inhalation challenges (e.g. methacholine) are stated to be more sensitive and less specific for a diagnosis of asthma than are indirect challenges (e.g. exercise, non-isotonic aerosols, mannitol, etc.). However, data surrounding comparative sensitivity and specificity for methacholine compared to mannitol challenges are conflicting. When methacholine is inhaled by deep total lung capacity (TLC) inhalations, deep inhalation inhibition of bronchoconstriction leads to a marked loss of diagnostic sensitivity when compared to tidal breathing (TB) inhalation methods. We hypothesized that deep inhalation methacholine methods with resulting bronchoprotection may be the explanation for conflicting sensitivity/specificity data.
\end{abstract}

Methods: We reviewed 27 studies in which methacholine and mannitol challenges were performed in largely the same individuals. Methacholine was inhaled by dosimeter TLC methods in 13 studies and by tidal breathing in 14 studies. We compared the rates of positive methacholine (stratified by inhalation method) and mannitol challenges in both asthmatics and non-asthmatics.

Results: When methacholine was inhaled by TLC inhalations the prevalence of positive tests in asthmatics, $60.2 \%$ (548/910), was similar to mannitol, 58.9\% (537/912). By contrast, when methacholine was inhaled by tidal breathing the prevalence of positive tests in asthmatics $83.1 \%$ (343/413) was more than double that of mannitol, $41.5 \%$ (146/351). In non-asthmatics, the two methacholine methods resulted in positive tests in 18.8\% (142/756) and 16.2\% $(27 / 166)$ by TLC and TB inhalations respectively. This compares to an overall $8.3 \%(n=76)$ positive rate for mannitol in 913 non-asthmatics.

Conclusion: These data support the hypothesis that the conflicting data comparing methacholine and mannitol sensitivity and specificity are due to the method of methacholine inhalation. Tidal breathing methacholine methods have a substantially greater sensitivity for a diagnosis of asthma than either TLC dosimeter methacholine challenge methods or mannitol challenge. Methacholine challenges should be performed by tidal breathing as per recent guideline recommendations. Methacholine (more sensitive) and mannitol (more specific) will thus have complementary diagnostic features.

Keywords: Methacholine inhalation test, Deep inhalation (TLC) method, Tidal breathing method, Mannitol inhalation test, Sensitivity, Specificity

*Correspondence: don.cockcroft@usask.ca

${ }^{2}$ Royal University Hospital, 103 Hospital Drive, Saskatoon, SK S7N0W8, Canada

Full list of author information is available at the end of the article

\section{Background}

Measurement of non-allergic or non-specific airway hyperresponsiveness (AHR) is a valuable tool in the clinical assessment of patients with possible asthma, those with asthma-like symptoms and non-diagnostic,

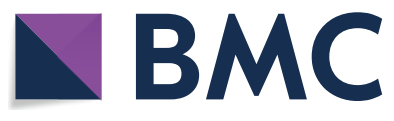

(c) The Author(s) 2020. This article is licensed under a Creative Commons Attribution 4.0 International License, which permits use, sharing, adaptation, distribution and reproduction in any medium or format, as long as you give appropriate credit to the original author(s) and the source, provide a link to the Creative Commons licence, and indicate if changes were made. The images or other third party material in this article are included in the article's Creative Commons licence, unless indicated otherwise in a credit line to the material. If material is not included in the article's Creative Commons licence and your intended use is not permitted by statutory regulation or exceeds the permitted use, you will need to obtain permission directly from the copyright holder. To view a copy of this licence, visit http://creativeco mmons.org/licenses/by/4.0/. The Creative Commons Public Domain Dedication waiver (http://creativecommons.org/publicdomain/ zero/1.0/) applies to the data made available in this article, unless otherwise stated in a credit line to the data. 
generally normal, lung function. Stimuli used to measure AHR have been classified as direct and indirect [1]. Direct stimuli act directly on airway smooth muscle receptors; examples include methacholine acting on muscarinic receptors and histamine acting on $\mathrm{H}_{1}$ receptors. Indirect stimuli act through one or more intermediate pathways most via mediators released from metachromatic inflammatory cells (mast cells, basophils); examples include exercise, eucapnic voluntary hyperpnea $(\mathrm{EVH})$, non-isotonic aerosols, propranolol, adenosine monophosphate (AMP) and dry powder mannitol [2]. Direct AHR reflects airway smooth muscle function, perhaps modulated by inflammation, while indirect AHR reflects airway inflammation $[1,2]$. The consensus is that direct AHR is highly sensitive for current asthma whereas indirect AHR is highly specific while being relatively insensitive particularly for mild and/or well controlled asthma [2].

Dry powder mannitol (Aridol ${ }^{\circledR}$ ) inhalation is an indirect challenge test [3] with several advantages. The advantages include the dose-response nature of the test (in contrast particularly to exercise and EVH), the lack of requirement for expensive and bulky equipment, and the fact that there is only a single method for administration of mannitol. In addition, we suspect that the mannitol challenge is less likely to be dose limited compared to other indirect challenges such as exercise, EVH, propranolol or AMP.

Studies comparing the diagnostic properties of the direct methacholine challenge and the indirect mannitol challenge have yielded conflicting results [329]. Several studies show that the two challenges have unexpectedly comparable sensitivity for asthma [7, 12, 13, 15] whereas other studies support the consensus that methacholine is more sensitive for a diagnosis of asthma $[19,22,25,26,29]$. A possible explanation is the observation from numerous studies that methacholine methods using a dosimeter with total lung capacity (TLC) inhalation (with a breath hold) demonstrate a marked loss of diagnostic sensitivity [30-32] due to deep inhalation bronchoprotection. This results in false negative challenges occurring in as many as $25 \%$ of overall methacholine tests and approaching 50\% in asthmatics with mild AHR [33].

We hypothesized that deep inhalation methacholine methods with resulting bronchoprotection may be the explanation for conflicting sensitivity/specificity data. We have compared the diagnostic performance of the two challenges by examining studies where the two tests were performed in the same individuals (mostly) and where the methacholine inhalation method was clearly described.

\section{Methods}

\section{Saskatoon studies}

We began by identifying 46 unique individuals from four studies performed in our laboratory. We included the 20 subjects from the most recent study [29], 18 (of 20) additional subjects from a second study [26] and 8 (of 20) subjects from two allergen challenge studies [27, 28]. For analysis we selected the first methacholine challenge performed in the four studies, the only mannitol study by the standard method [3] from 2 studies $[26,29]$ and the pre-allergen mannitol challenge from the two allergen challenge studies [27, 28]. The methacholine challenges were done with the two minute tidal breathing method [34] in three studies [26-28] and by the tidal breathing vibrating mesh nebulizer volumetric method $(0.5 \mathrm{~mL}$ methacholine nebulized to completion, 1.5 to 2.5 min tidal breathing) [35] in one [29]. A normal result is a provocation concentration causing a fall in forced expired volume in $1 \mathrm{~s}\left(\mathrm{FEV}_{1}\right)$ of $20 \%\left(\mathrm{PC}_{20}\right)$ of $>16 \mathrm{mg} / \mathrm{mL}$ for the former method [34] and non-cumulative provocation dose causing a $20 \% \mathrm{FEV}_{1}$ fall $\left(\mathrm{PD}_{20}\right)$ of $>400 \mu \mathrm{g}$ for the latter [35]. For analysis, $\mathrm{PC}_{20}$ values were converted to $\mathrm{PD}_{20} \mathrm{~s}$ based on the validated relationship that a $\mathrm{PC}_{20}$ of $16 \mathrm{mg} / \mathrm{mL}$ equates to a post evaporation noncumulative $\mathrm{PD}_{20}$ of $400 \mu \mathrm{g}$ [35-38]. A normal (negative) mannitol result is a cumulative $\mathrm{PD}_{15}>635 \mathrm{mg}$ [3]. Mannitol responsiveness was also assessed as the doseresponse slope (DRS) so that a value was available for all individuals. Fractional exhaled nitric oxide (FeNO) [39] was available for all individuals. Data were analyzed with a computerized statistics programme, (Statistix 9 Analytical Software, Tallahassee, FL, USA). All data were $\log$ transformed. Log methacholine $\mathrm{PD}_{20}$ was compared to log mannitol DRS with linear regression and both log methacholine $\mathrm{PD}_{20}$ and $\log$ mannitol DRS were regressed with log FeNO.

\section{Other studies}

Through a PubMed search, we identified 23 additional studies [3-25] that met the following criteria:

1. Mannitol testing was performed by the standardized protocol and results reported as the $\mathrm{PD}_{15}$ [3].

2. Methacholine challenges by various methods were done in the same subjects, with one exception where more subjects had methacholine tests than mannitol tests [25].

3. The methacholine inhalation method was described.

4. The definitions of "asthma" and "non-asthma" were outlined. 


\section{Results}

\section{Saskatoon studies}

All 46 subjects had mild asthma and were not using inhaled corticosteroids (ICS). Age $=26.5 \pm 8.5$ (SD) years, height $=170 \pm 9.6 \mathrm{~cm}, \mathrm{FEV}_{1}=3.45 \pm 0.75 \mathrm{~L}$ and $91.5 \pm 11.2 \%$ predicted. The methacholine $\mathrm{PD}_{20}$ was $\leq 400 \mu \mathrm{g}$ in 45 of 46 (Fig. 1) and the geometric mean was 68.0 (95\% CI 47.8-97.0) $\mu$ g. The mannitol challenge was positive $\left(\mathrm{PD}_{15} \leq 635 \mathrm{mg}\right.$ cumulative dose [3]) in 22 of 46 . The $635 \mathrm{mg} \mathrm{PD} 15$ cut off equates to a DRS of 42.3 (mg/\%fall) (Fig. 1). There was a moderate positive correlation between log methacholine $\mathrm{PD}_{20}$ and $\log$ mannitol DRS ( $\mathrm{r}=0.51, \mathrm{p}=0.0003$, Fig. 2). Both $\log$ methacholine $\mathrm{PD}_{20}$ and log mannitol DRS correlated significantly and negatively with $\log$ FeNO $(r=0.34$ and $r=0.50$, respectively, Fig. 3): The correlation with FeNO was stronger for mannitol $(p=0.0004)$ than for methacholine $(\mathrm{p}=0.02)$.

\section{Methacholine dosimeter TLC studies}

Of 27 studies where methacholine and mannitol were compared [3-29] 13 used dosimeter TLC methods for methacholine inhalation [3-15]. These 13 studies are summarized in Table 1 . The cut point for defining a positive methacholine test ranged from a cumulative $\mathrm{PD}_{20}$ of 7.8 to $10.2 \mu \mathrm{mol}[3-6,8-10,14]$, or a non-cumulative $\mathrm{PC}_{20}$ of 8 [12] or $16[7,11,13,15]$ $\mathrm{mg} / \mathrm{mL}$ (Table 2). Assuming nebulizer characteristics similar to the methods outlined by the ATS in 2000 [40], these would equate approximately to a non-cumulative post-evaporation $\mathrm{PD}_{20}$ between 200 and $400 \mu \mathrm{g}$. Four investigations studied known asthmatics [3, 6, 8, 15]; in one of these [3] asthma was defined by indirect AHR to hypertonic saline. Four studies involved subjects with "doctor diagnosed asthma" [5, 9, 12, 13], while three other studies defined asthma from a cohort with nondiagnostic symptoms, by a respiratory physician $[7,10]$ or panel [14] blinded to AHR data, and the final study defined asthma based on a positive AHR test (mannitol or methacholine) [11]. The non-asthmatic cohorts included subjects remaining in 5 studies after asthmatics had been defined $[5,7,9,10,14]$, one study with normal controls [13], one study with a highly select group of asymptomatic (non-asthmatic) individuals with positive methacholine tests [4] and one study where non-asthma was define by negative AHR to both methacholine and mannitol [11].

Results from the 12 asthma studies (Table 2) show similar sensitivity with positive methacholine tests in $60.2 \%$ (548 of 910) asthmatics and positive mannitol tests in $58.9 \%$ (537 of 912) asthmatics. When the two studies in which asthma was defined based on presence of AHR

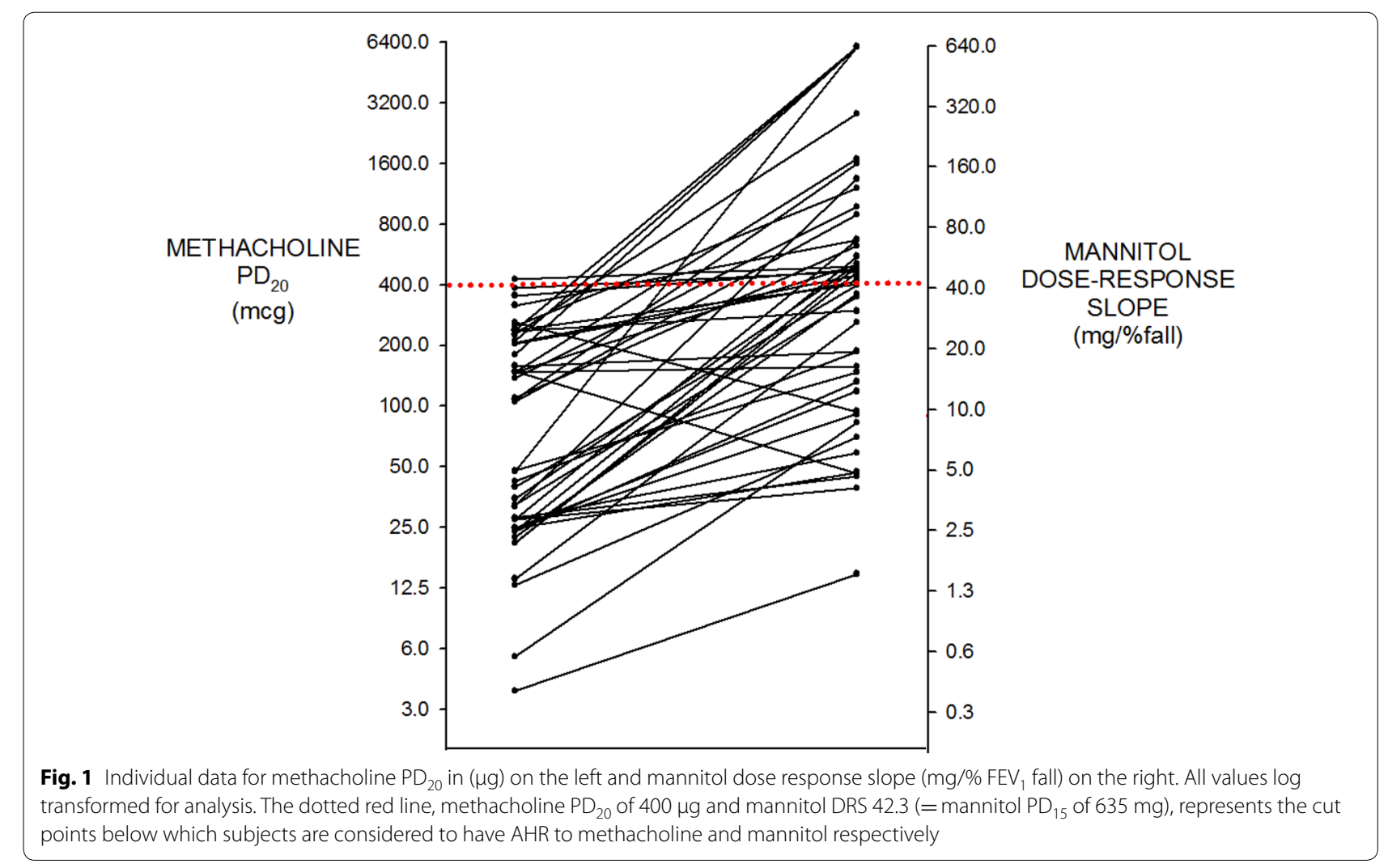




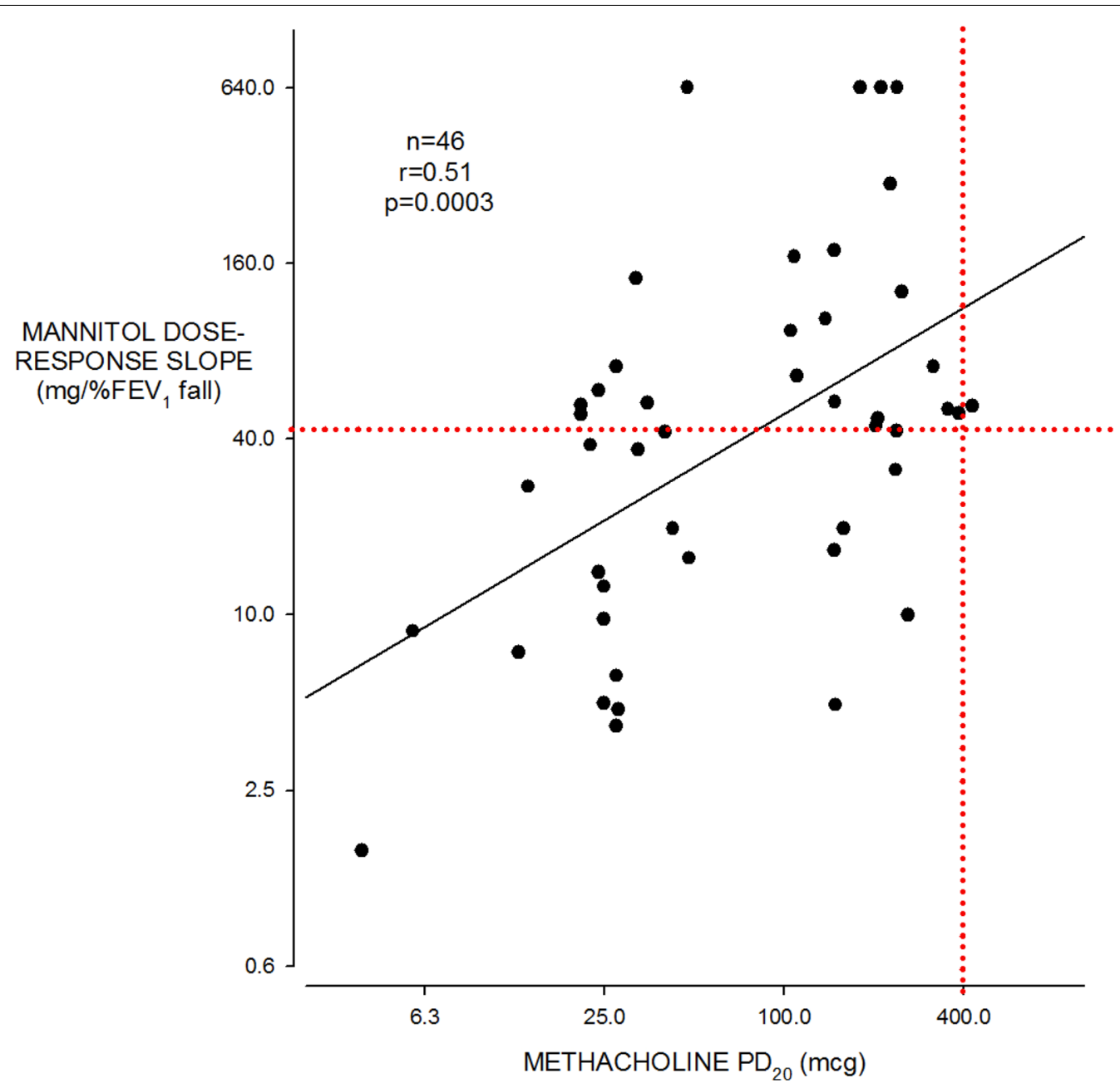

Fig. 2 Mannitol DRS (mg/\% FEV fall) on the vertical axis) and methacholine $\mathrm{PD}_{20}(\mu \mathrm{g})$ on the horizontal axis. The dotted red lines indicate the cut points below which the values indicate AHR to mannitol $(42.3 \mathrm{mg} / \% \mathrm{FEV}$, fall) or methacholine $(400 \mu \mathrm{g})$ respectively. All values log transformed for analysis

$[3,11]$ were excluded, the results were similar with $58.8 \%$ and $57.3 \%$ positive for methacholine and mannitol respectively (Table 2). In the 8 studies with non-asthma cohorts $[4,5,7,9-11,13,14]$, there were approximately twice as many positive methacholine tests $(18.8 \%$ or 142 of 756) compared to mannitol tests (9.5\% or 72 of 756 ) Table 2) Excluding the two studies in which AHR was either an inclusion [4] or an exclusion [11] criterion produced similar results, $17.4 \%$ and $9.8 \%$ positive for methacholine and mannitol respectively (Table 2).

\section{Methacholine tidal breathing studies}

The 13 studies using tidal breathing methacholine methods [16, 18-29] compared to mannitol are summarized in Table 3. A fourteenth study that used histamine as the direct stimulus was also included [17].
Methacholine was inhaled by 2 min of tidal breathing from a jet nebulizer in 9 studies [16, 19, 21, 22, 24-28] or from a vibrating mesh nebulizer in one study [29]. The remaining four studies were defined as tidal breath dosimeter methods $[17,18,20,23]$. The cut point definitions for a positive methacholine test (Table 4) included a cumulative $\mathrm{PD}_{20}$ of 1 to $2 \mathrm{mg}(5.1-10.2 \mu \mathrm{mol})$ $[17,18,20]$ or $8 \mu \mathrm{mol}$ [23], a non-cumulative $\mathrm{PC}_{20}$ of 8 [23] or $16[16,19,21,24-28] \mathrm{mg} / \mathrm{mL}$ and a noncumulative post-evaporation $\mathrm{PD}_{20}$ of $400 \mu \mathrm{g}$ [29]. Once again, assuming nebulizer characteristics similar to the methods outlined by the ATS in 2000 [40] these would equate approximately to a non-cumulative postevaporation $\mathrm{PD}_{20}$ between 200 and $400 \mu \mathrm{g}$. Known asthmatics were evaluated in 11 studies [16, 17, 20-22, 25-29] doctor diagnosed asthma in athletes in two 


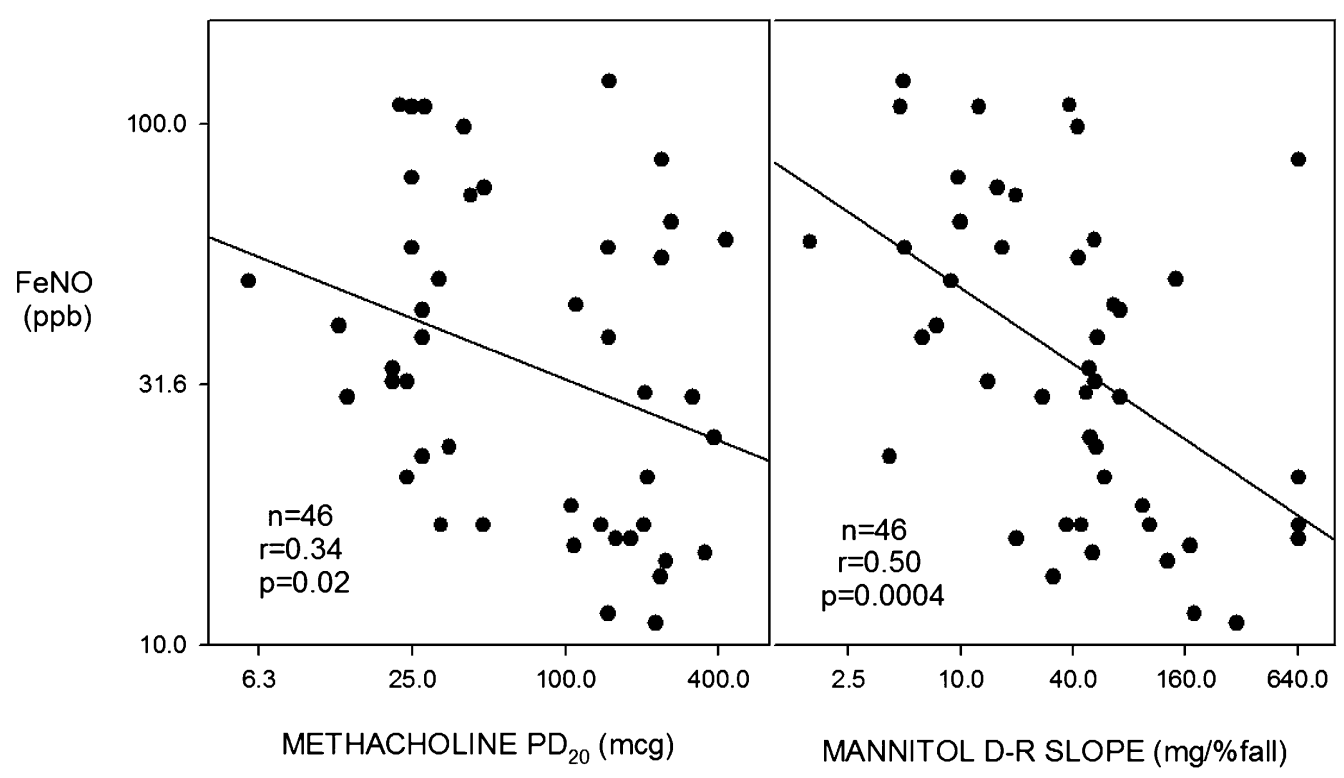

Fig. 3 Correlation of FeNO on the vertical axis with methacholine $\mathrm{PD}_{20}(\mu \mathrm{g})$ on the horizontal axis left panel and mannitol DRS ( $\mathrm{mg} / \%$ FEV 1 fall) on the horizontal axis right panel. All values log transformed

Table 1 Mannitol compared to methacholine deep inhalation studies

\begin{tabular}{|c|c|c|c|c|c|c|}
\hline & Refs & & $\mathbf{n}$ & Asthma definition & $\mathbf{n}$ & Non-asthma definition \\
\hline & Author & Ref & & & & \\
\hline 1 & Anderson et al. & [3] & 25 & Asthma with indirect AHR to hypertonic saline & 0 & \\
\hline 2 & Pjorsgerg et al. & [4] & 0 & & 16 & Asymptomatic positive MCT \\
\hline 3 & Miedinger et al. & [5] & 14 & $\begin{array}{l}\text { Asthma defined by board physician from } \\
101 \text { Swiss firefighters }\end{array}$ & 87 & Defined by board MD \\
\hline 4 & Pjorsberg et al. & [6] & 53 & Asthmatics not using ICS & 0 & \\
\hline 5 & Anderson et al. & [7] & 240 & $\begin{array}{l}240 \text { of } 375 \text { with symptoms and unconfirmed asthma } \\
\text { diagnosis made by AHR-blinded physician }\end{array}$ & 135 & Defined by AHR-blinded physician \\
\hline 6 & Gade et al. & [8] & 48 & $\begin{array}{l}\text { Asthmatics same day tests in random order } \\
21 \text { using ICS }\end{array}$ & 0 & \\
\hline 7 & Miedinger et al. & [9] & 42 & $\begin{array}{l}\text { Doctor diagnosed (MD-Dx) asthma } \\
235 \text { Swiss armed forces conscripts }\end{array}$ & 193 & Non-asthmatic conscripts \\
\hline 8 & Sverrild et al. & [10] & 51 & $\begin{array}{l}\text { From } 238 \text { randomly selected subjects } \\
\text { Dx by physician blinded to AHR results }\end{array}$ & 187 & Blinded physician \\
\hline 9 & Cancelliere et al. & [11] & 11 & $\begin{array}{l}\text { From } 28 \text { with asthma-like } S x \\
\text { Dx defined by positive AHR }\end{array}$ & 17 & Defined by negative AHR \\
\hline 10 & Manoharan et al. & [12] & 123 & MD-Dx asthma & 0 & \\
\hline 11 & Kim et al. & {$[13]$} & 50 & MD-Dx asthma & 54 & Normal controls \\
\hline 12 & Backer et al. & {$[14]$} & 122 & $\begin{array}{l}\text { From } 190 \text { referred for possible asthma } \\
\text { Dx by panel without AHR results }\end{array}$ & 68 & Defined by panel without AHR results \\
\hline 13 & Park et al. & [15] & 134 & Asthmatic children 32 using ICS & 0 & \\
\hline
\end{tabular}

studies [18, 23] and, from a group of symptomatic subjects, asthma diagnosed by a respiratory physician prior to AHR determination in one study [24] (Table 4). The 7 studies involving non-asthmatic cohorts included non-asthmatic controls in four [16, 17, 20, 25], the athletes remaining after doctor diagnosed asthma had been defined in two [18, 23], and the symptomatic individuals remaining after asthma was diagnosed [24] (Table 4). 


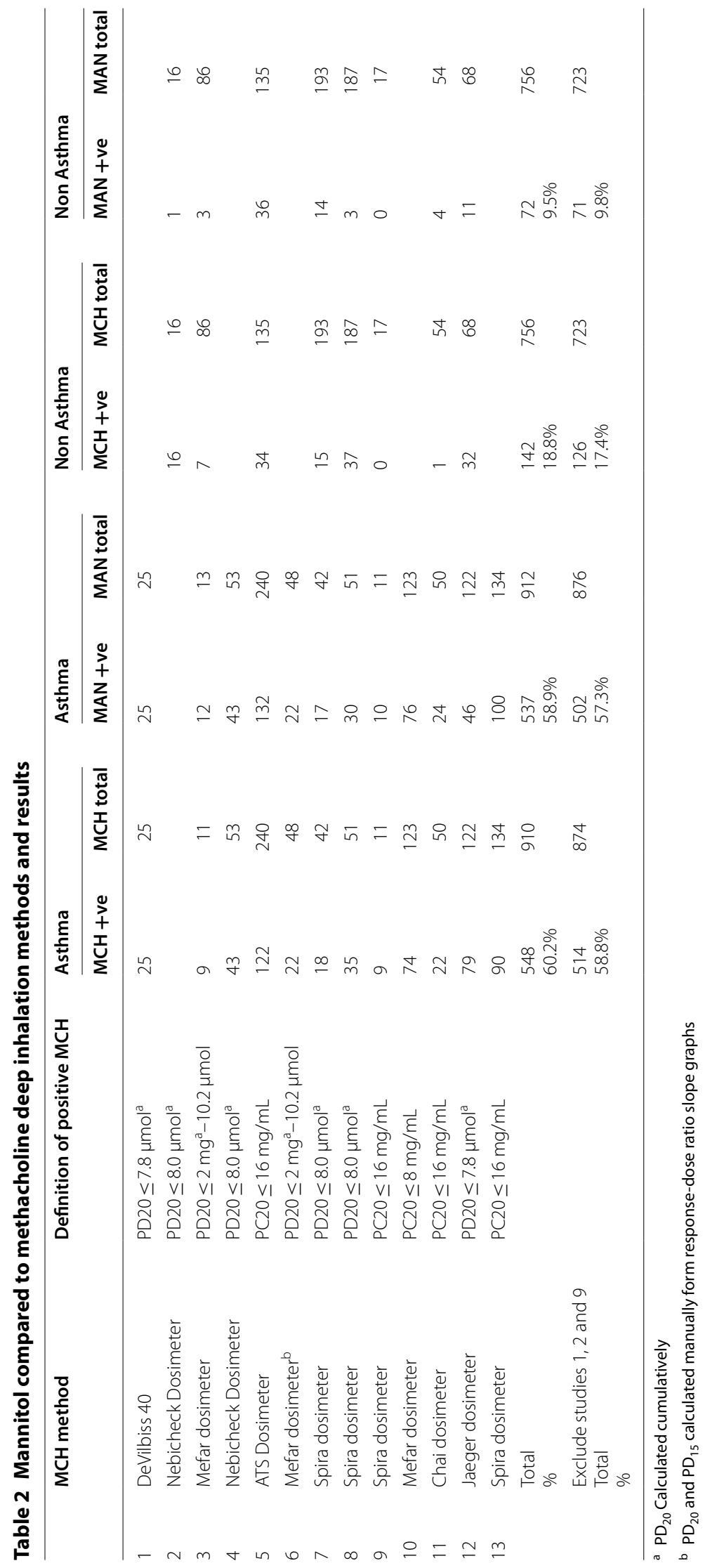


Table 3 Mannitol compared to methacholine tidal breathing studies

\begin{tabular}{|c|c|c|c|c|c|c|}
\hline & \multicolumn{2}{|l|}{ Reference } & \multirow[t]{2}{*}{$\mathbf{n}$} & \multirow[t]{2}{*}{ Asthma definition } & \multirow[t]{2}{*}{$\mathbf{n}$} & \multirow[t]{2}{*}{ Non asthma definition } \\
\hline & Author & Ref \# & & & & \\
\hline 1 & Subbarao et al. & {$[16]$} & 25 & Asthmatic children with positive methacholine test & 10 & Non asthmatic methacholine negative \\
\hline 2 & Koskelka et al. & {$[17]$} & 37 & $\begin{array}{l}\text { Mild corticosteroid naïve asthmatics } \\
\text { NB: Histamine }\end{array}$ & 10 & Non asthmatic controls \\
\hline 3 & Sue-Chu et al. & {$[18]$} & 10 & MD-Dx asthma from 58 cross country skiers & 48 & Non asthmatic cross country skiers \\
\hline 4 & Andregnette et al. & {$[20]$} & 30 & Current asthmatic children & 0 & \\
\hline 5 & Aronsson et al. & {$[19]$} & 34 & Asthmatics & 18 & Non asthmatic controls \\
\hline 6 & Lemiere et al. & {$[21]$} & 30 & Occupational asthmatics & 0 & \\
\hline 7 & Andregnette et al. & {$[22]$} & 23 & Asthmatic children with EIB symptoms & 0 & \\
\hline 8 & Toennesen et al. & {$[23]$} & 18 & MD-Dx asthma from 57 elite athletes & 39 & Non asthmatic Elite athletes \\
\hline 9 & Porpodis et al. & {$[24]$} & 67 & From 88 subjects with asthma-like symptoms & 21 & Symptoms but no asthma \\
\hline 10 & Gutierrez et al. & {$[25]$} & 156 & Asthmatic children & 38 & Non asthmatic controls \\
\hline 11 & Cockcroft et al. & {$[26-28]$} & 26 & Mild asthma no ICS & 0 & \\
\hline 12 & Blais et al. & [29] & 20 & Mild asthma no ICS & 0 & \\
\hline
\end{tabular}

Results are summarized in Table 4. Methacholine tests were more than twice as likely to be positive in asthmatics (i.e. methacholine more sensitive) than was mannitol. The positive rate was $83.1 \%$ (343 of 413) for methacholine and $41.5 \%$ (146 of 351) for mannitol. In the non-asthmatics methacholine was more likely to be positive at $16.2 \%$ (27 of 166 ) than was mannitol at $2.5 \%$ (4 of 157).

When both methacholine TLC and methacholine TB studies were combined, the overall rate of a positive mannitol challenge in non-asthmatics was $8.3 \%$ or 76 of 913.

\section{Discussion}

These data provide strong support for the hypothesis that tidal breathing direct methacholine challenge methods yield results that are substantially more sensitive for asthma than does the indirect mannitol challenge. By contrast, when methacholine is inhaled by TLC methods, the diagnostic sensitivity falls to a level similar to that seen with mannitol.

Many investigators have found that AHR correlates with airway inflammation, primarily with eosinophils, as assessed by broncho-alveolar lavage (BAL), induced sputum cell counts or indirectly by FeNO or blood eosinophils [41-47]. Initial studies addressed methacholine (direct) AHR and BAL eosinophils and metachromatic cells (basophils and mast cells) [41, 42]. Subsequent studies addressed, in addition, indirect challenges, AMP [43, 44], bradykinin [45] and mannitol [26, 29, 46, 47]. While these investigations show a fair to good correlation between methacholine AHR and primarily eosinophilic inflammation, the indirect AHR tests correlate substantially better with inflammation [43-46]. The results from our combined investigations [26-29], using FeNO as an indirect measure of eosinophilic airway inflammation, are in keeping with this as shown in Fig. 3. Relatively few studies have addressed the potentially more important [48] metachromatic cells (mast cells and/or basophils) $[41,42,47]$. There is a hint from these studies that airway metachromatic cell inflammation may correlate better with AHR than does eosinophilic airway inflammation.

AHR improves with anti-inflammatory therapeutic strategies including allergen avoidance environmental control [49, 50] and ICS [51-53]. In keeping with the above observations, indirect AHR (AMP [49-52]) shows greater improvement with these treatments than does direct methacholine AHR. Mannitol responsiveness improves greatly after ICS treatment [53] and can provide a useful predictive marker of a pending asthma exacerbation during ICS tapering [54]. Although direct AHR has been proposed to monitor and guide asthma treatment [55], indirect AHR may provide a particularly valuable tool as a guide to monitoring asthma control [56]. In fact, non-responsiveness to indirect challenge (e.g. AMP, mannitol) may be a goal for adequate asthma control with ICS [56]. This, of course, is consistent with a positive indirect AHR challenge (including mannitol) being insensitive for the diagnosis of well controlled asthma.

Deep inhalations to TLC produce potent bronchodilation and bronchoprotection, the latter greater than the former, in normal individuals but initially stated to not occur in asthmatics [57]. It had become apparent that this marked bronchoprotective 


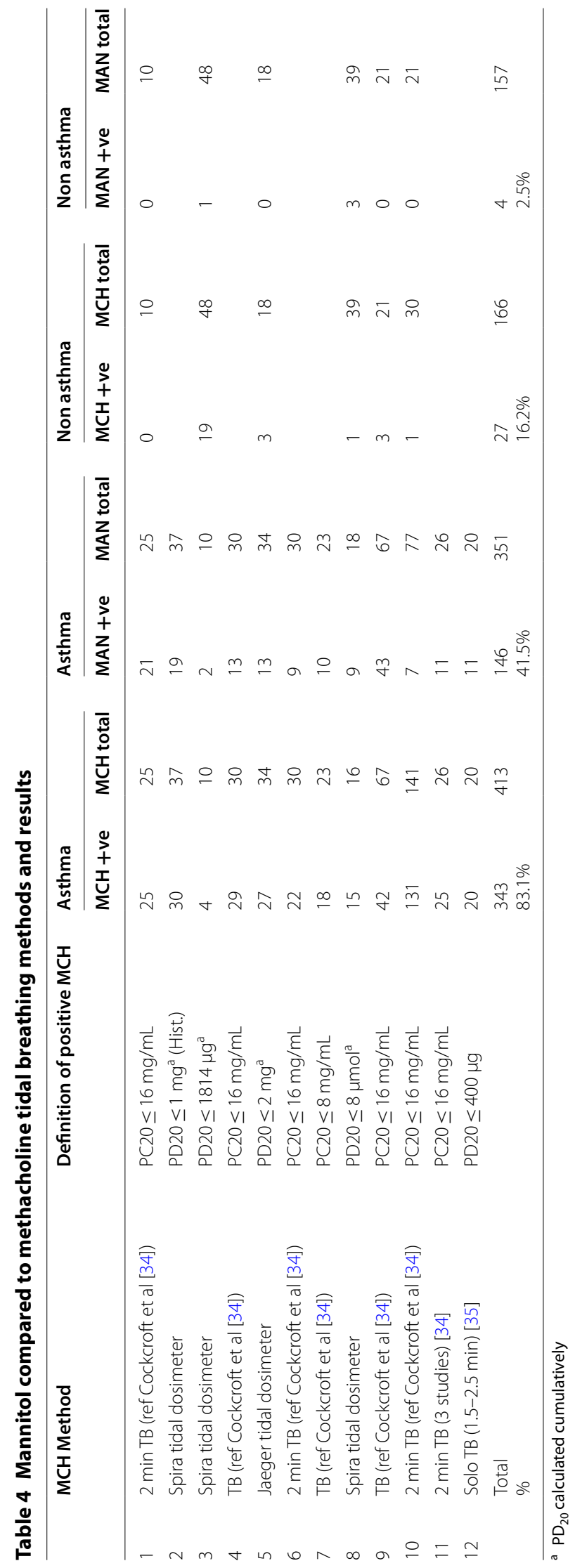


effect extends to mild asthmatics [30-33] and, in all likelihood may well extend to well controlled asthmatics. Although not seen in all studies [58], eosinophilic airway inflammation impairs the bronchoprotective effect of deep inhalation [26, 59, 60]. Anti-inflammatory strategies, both allergen avoidance [61] and oral/inhaled corticosteroid [62], can restore or improve the deep inhalation bronchoprotection in asthmatics. In one study, lack of bronchoprotection (methacholine) and elevated levels FeNO as an indirect measure of airway inflammation were associated with indirect AHR to mannitol [26].

Collectively, these data suggest that airway inflammation (eosinophilic particularly), indirect AHR and loss of deep inhalation bronchoprotection will occur together in asthmatics. Conversely, deep inhalation bronchoprotection and low levels of airway inflammation will be associated with little if any indirect AHR [26]. Avoidance of TLC inhalations during methacholine inhalation will therefore result in many more positive direct challenge tests in mild (and possibly well controlled) asthmatics with no indirect AHR and minimal airway inflammation. This is confirmed by our current review.

Deep inhalation bronchoprotection during methacholine challenges is an important and underappreciated phenomenon [33]. This has been shown by three studies from our laboratory [30-32] and supported by studies from other laboratories [63, 64]. This was first suggested in a study of 40 individuals [30] comparing the two methacholine methods outlined in the ATS document [40]. Follow up investigations demonstrated that asthmatics with negative TLC dosimeter methacholine tests had positive challenges when the identical dosimeter dose was administered with sub-maximal inhalations (approximately half TLC) [31] and that many asthmatics with positive tidal breathing methacholine challenges were negative when five TLC breaths were incorporated at equal intervals throughout the 2 min of tidal breathing [32]. These latter two studies provide convincing evidence of the bronchoprotective effect of deep TLC inhalations in many individuals with mild asthma. Our summary data from 55 asthmatic individuals with positive tidal breathing methacholine tests revealed that 13 (24\%) had negative five TLC breath dosimeter methacholine tests [33]. This represents 50\% of asthmatics with a tidal breathing $\mathrm{PC}_{20}$ between 2 and $16 \mathrm{mg} / \mathrm{mL}$ (post evaporation non-cumulative $\mathrm{PD}_{20}$ between 50 and $400 \mu \mathrm{g})$. This is exactly the range where a positive diagnostic methacholine challenge, done in individuals with symptoms suggestive of asthma and normal spirometry, is likely to fall. In this population, the TLC dosimeter methacholine method could, therefore, produce a false negative rate approaching $50 \%$ for individuals with asthma and mild AHR. For these reasons the recent methacholine guidelines have strongly suggested that methacholine challenges be performed with tidal breathing methods with a non-TLC dosimeter method as a second option [36]. By contrast, as anticipated by the above data, our recent study documented that removal of TLC inhalations from the mannitol challenge did not affect the result [29].

It is difficult to accurately comment on sensitivity and specificity of the different tests from the available references. A reasonable estimate of diagnostic sensitivity can be made by assessing the rate of positivity in subjects determined to have asthma. Based on this approach the tidal breathing methacholine test is about twice as sensitive for "asthma" as the mannitol test $(83.1 \%$ and $41.5 \%$ respectively) in the studies assessed, whereas the sensitivities of TLC methacholine and mannitol tests were similar, at approximately $60 \%$ for both in the studies included. These data suggest that the loss of diagnostic sensitivity of the methacholine test when using a TLC dosimeter method is significant enough to make the sensitivity equivalent to an indirect challenge. It is even more difficult to comment accurately on specificity without a larger cohort of normal nonasthmatic individuals. The observation that there were fewer positive mannitol tests (about half) compared to methacholine tests in non-asthmatics is consistent with the consensus that indirect challenges, including mannitol, are more specific for asthma [2, 65]. The difficulties are further compounded both by the lack of an independent gold standard for the diagnosis of asthma and by the requirement for the symptoms under investigation to be clinically current, i.e. within the past few days $[65,66]$.

We suspect that these results would translate to indirect challenges other than mannitol; these include AMP, propranolol, hypertonic saline, EVH and exercise (EIB). It is likely that all these indirect challenges would show minimal if any deep inhalation bronchoprotection. EVH and EIB are particularly important. It would, however, be difficult to design a study with and especially without deep inhalations for these two, especially for EVH.

Indirect challenges require a substantially larger dose of stimulus than direct challenges, up to or greater than three orders of magnitude $\mathrm{mg}$ for $\mathrm{mg}$ or $\mathrm{mmol}$ for mmol [65]. For example, the top doses for mannitol and methacholine are 635 (cumulative) and $0.4 \mathrm{mg}$ (noncumulative) respectively. It is possible that mannitol might be more sensitive than many other indirect stimuli because the challenge is less likely to be "dose limited" [65]. There are physiologic limits on the "dose" 
of stimulus that can be achieved with exercise or EVH, and, because of the large doses needed, a solubility limit on the doses that can be achieved with AMP or propranolol [65]. Mannitol, by contrast, is a dry powder inhalation and the dose is not limited by solubility. There is only one mannitol inhalation method [3]. However, the large number of different methacholine methods represents a difficulty when attempting to compare data. A conservative estimate is that there were at least 6 different TLC dosimeter methods and 4 different TB methods in the studies evaluated. The best case estimate is that these methods equated to a post-evaporation methacholine $\mathrm{PD}_{20}$ range of only twofold $(200-400 \mu \mathrm{g})$, however that is speculation without knowledge of the operating characteristics of the different nebulizers used.

\section{Conclusion}

The discordance between methacholine and mannitol comparisons can be explained by the method of methacholine inhalation. Tidal breathing methacholine tests are substantially more sensitive than mannitol tests for a diagnosis of asthma and equally more sensitive than TLC dosimeter methacholine methods. In order to preserve a high diagnostic sensitivity, methacholine challenges should be performed by tidal breathing [33, $36,65]$, thus providing data that are complementary to the more specific mannitol challenge.

\begin{abstract}
Abbreviations
$\mathrm{FEV}_{1}$ : Forced expired volume in $1 \mathrm{~s} ; \mathrm{PC}_{20}$ : Provocation concentration causing a $20 \%$ FEV fall; $\mathrm{PD}_{20}$ : Provocation dose causing a $20 \% \mathrm{FEV}$ f fall; $\mathrm{MCH}$ : Methacholine; MAN: Mannitol; AHR: Airway hyperresponsiveness; DRS: Dose response slope; TLC: Total lung capacity; TB: Tidal breathing; EVH: Eucapnic voluntary hyperpnea; AMP: Adenosine monophosphate; FeNO: Fractional exhaled nitric oxide; ICS: Inhaled corticosteroid; MD-Dx: Doctor diagnosed; SD: Standard deviation; Cl: Confidence interval; BAL: Broncho-alveolar lavage.
\end{abstract}

\section{Acknowledgements}

The authors thank Jacquie Bramley for assistance in preparation of the manuscript.

\section{Authors' contributions}

Study design: DWC; data collection: DWC, BED, CMB; data analysis: DWC, BED, $C M B$; manuscript preparation DWC. All authors read and approved the final manuscript.

\section{Funding}

This study was not funded. CMB received a summer student support grant from the CSACI.

\section{Availability of data and materials \\ All data are available from the corresponding author on reasonable request} don.cockcroft@usask.ca.

\section{Ethics approval and consent to participate}

Not applicable.

\section{Consent for publication}

Not applicable.

\section{Competing interests}

CMB and BED have no competing interests, DWC is a member of the medical advisory board of Methapham Canada.

\section{Author details}

${ }^{1}$ Department of Medicine, University of Saskatchewan, Saskatoon, SK, Canada.

${ }^{2}$ Royal University Hospital, 103 Hospital Drive, Saskatoon, SK S7NOW8, Canada.

Received: 29 November 2019 Accepted: 28 January 2020

Published online: 11 February 2020

\section{References}

1. Pauwels R, Joos G, Van Der Straeten M. Bronchial hyperresponsiveness is not bronchial hyperresponsiveness is not bronchial asthma. Clin Allergy. 1988;18(4):317-21.

2. Joos GF, O'Connor B, Anderson SD, Chung F, Cockcroft DW, Dahlen B, et al. Indirect airway challenges. Eur Respir J. 2003;21 (6):1050-68.

3. Anderson SD, Brannan J, Spring J, Spalding N, Rodwell LT, Chan K, et al. A new method for bronchial-provocation testing in asthmatic subjects using a dry powder of mannitol. Am J Respir Crit Care Med. 1997;156(3 Pt 1):758-65.

4. Porsbjerg C, Rasmussen L, Thomsen SF, Brannan JD, Anderson SD, Backer V. Response to mannitol in asymptomatic subjects with airway hyperresponsiveness to methacholine. Clin Exp Allergy. 2007;37(1):22-8.

5. Miedinger D, Chhajed PN, Tamm M, Stolz D, Surber C, Leuppi JD. Diagnostic tests for asthma in firefighters. Chest. 2007;131(6):1760-7.

6. Porsbjerg C, Brannan JD, Anderson SD, Backer V. Relationship between airway responsiveness to mannitol and to methacholine and markers of airway inflammation, peak flow variability and quality of life in asthma patients. Clin Exp Allergy. 2008;38(1):48-50.

7. Anderson SD, Charlton B, Weiler JM, Nichols S, Spector SL, Pearlman DS. Comparison of mannitol and methacholine to predict exercise-induced bronchoconstriction and a clinical diagnosis of asthma. Respir Res. 2009;10:4.

8. Gade E, Thomsen SF, Porsbjerg C, Backer V. The bronchial response to mannitol is attenuated by a previous methacholine test: but not vice versa. Clin Exp Allergy. 2009;39(7):966-71.

9. Miedinger D, Mosimann N, Meier R, Karli C, Florek P, Frey F, et al. Asthma tests in the assessment of military conscripts. Clin Exp Allergy. 2010:40(2):224-31.

10. Sverrild A, Porsbjerg C, Thomsen SF, Backer V. Airway hyperresponsiveness to mannitol and methacholine and exhaled nitric oxide: a randomsample population study. J Allergy Clin Immunol. 2010;126(5):952-8.

11. Cancelliere N, Bobolea I, López-Carrasco V, Barranco P, López-Serrano C, Quirce S. Comparative study of bronchial hyperresponsiveness to methacholine and mannitol in the initial diagnosis of asthma. J Investig Allergol Clin Immunol. 2013;23(5):361-2.

12. Manoharan A, Lipworth BJ, Craig E, Jackson C. The potential role of direct and indirect bronchial challenge testing to identify overtreatment of community managed asthma. Clin Exp Allergy. 2014;44(10):1240-5.

13. Kim MH, Song WJ, Kim TW, Jin HJ, Sin YS, Ye YM, et al. Diagnostic properties of the methacholine and mannitol bronchial challenge tests: a comparison study. Respirology. 2014;19(6):852-6.

14. Backer V, Sverrild A, Ulrik CS, Bødtger U, Seersholm N, Porsbjerg C. Diagnostic work-up in patients with possible asthma referred to a university hospital. Eur Clin Respir J. 2015;2:27768.

15. Park YA, Park HB, Kim YH, Sul IS, Yoon SH, Kim HR, et al. Airway hyperresponsiveness to mannitol and methacholine and exhaled nitric oxide in children with asthma. J Asthma. 2017;54(6):644-51.

16. Subbarao P, Brannan JD, Ho B, Anderson SD, Chan HK, Coates AL. Inhaled mannitol identifies methacholine-responsiveness children with active asthma. Pediatr Pulmonol. 2000;29(4):291-8.

17. Koskela HO, Hyvärinen L, Brannan JD, Chan HK, Anderson SD. Responsiveness to three bronchial provocation tests in patients with asthma. Chest. 2003;124(6):2171-7.

18. Sue-Chu M, Brannan JD, Anderson SD, Chew N, Bjemer L. Airway hyperresponsiveness to methacholine, adenosine 5-monophosphate, mannitol, eucapnic voluntary hyperpnoea and field exercise challenge in elite cross-country skiers. Br J Sports Med. 2010;44(11):827-32. 
19. Andregnette-Roscigno V, Fernández-Nieto M, Del Potro MG, Aguado E, Sastre J. Methacholine is more sensitive than mannitol for evaluation of bronchial hyperresponsiveness in children with asthma. J Allergy Clin Immunol. 2010;126(4):869-71.

20. Aronsson D, Tufveseson E, Bjemer L. Comparison of central and peripheral airway involvement before and during methacholine, mannitol and eucapnic hyperventilation challenges in mild asthmatics. Clin Respir J. 2011;5(1):10-8.

21. Lemiere C, Miedinger D, Jacob V, Chaboillez S, Tremblay C, Brannan JD. Comparison of methacholine and mannitol bronchial provocation tests in workers with occupational asthma. J Allergy Clin Immunol. 2012;129(2):555-6.

22. Andregnette-Roscigno V, Fernández-Nieto M, Arochena L, Garcia Del Potro M, Aguado E, Sastre J. Methacholine is more sensitive than mannitol for evaluation of bronchial hyper-responsiveness in youth athletes with exercise-induced bronchoconstriction. Pediatr Allergy Immunol. 2012;23(5):501-3.

23. Toennesen LL, Porsbjerg C, Pedersen L, Backer V. Predictors of airway hyperresponsiveness in elite athletes. Med Sci Sports Exerc. 2015;47(5):914-20.

24. Porpodis K, Domvri K, Kontakiotis T, Fouka E, Kontakioti E, Zarogoulidis K, et al. Comparison of diagnostic validity of mannitol and methacholine challenges and relationship to clinical status and airway inflammation in steroid-naïve asthmatic patients. J Asthma. 2017;54(5):520-9.

25. Jara-Gutierrez P, Aguado E, Del Potro MG, Fernández-Nieto M, Mahillo I, Sastre J. Comparison of impulse oscillometry and spirometry for detection of airway hyperresponsiveness to methacholine, mannitol, and eucapnic voluntary hyperventilation in children. Pediatr Pulmonol. 2019. https://doi.org/10.1002/ppul.24409.

26. Davis BE, Stewart SL, Martin AL, Cockcroft DW. Low levels of fractional exhaled nitric oxide and deep inhalation bronchoprotection are associated with mannitol non-responsiveness in asthma. Respir Med. 2014;108(6):859-64.

27. Amakye DO, Davis BE, Martin AL, Peters GE, Cockcroft DW. Refractoriness to inhaled mannitol 3 hours after allergen challenge. Ann Allergy Asthma Immunol. 2013;111(3):182-4.

28. Davis BE, Amakye DO, Cockcroft DW. Airway responsiveness to mannitol $24 \mathrm{~h}$ after allergen challenge in atopic asthmatics. Allergy. 2015;70(6):682-8.

29. Blais CM, Davis BE, Cockcroft DW. The effect of deep inhalation on mannitol responsiveness. Clin Exp Allergy. 2019. https://doi.org/10.1111/ cea.13543 (in press)

30. Cockcroft DW, Davis BE, Todd DC, Smycniuk AJ. Methacholine challenge: comparison of two methods. Chest. 2005;127(3):839-44.

31. Todd DC, Davis BE, Hurst TS, Cockcroft DW. Dosimeter methacholine challenge: comparison of maximal versus submaximal inhalations. J Allergy Clin Immunol. 2004;114(3):517-9.

32. Allen ND, Davis BE, Hurst TS, Cockcroft DW. Difference between dosimeter and tidal breathing methacholine challenge: contributions of dose and deep inspiration bronchoprotection. Chest. 2005;128(6):4018-23.

33. Cockcroft DW, Davis BE. The bronchoprotective effect of inhaling methacholine by using total lung capacity inspirations has a marked influence on the interpretation of the test result. J Allergy Clin Immunol. 2006;117(6):1244-8.

34. Cockcroft DW, Killian DN, Mellon JJ, Hargreave FE. Bronchial reactivity to inhaled histamine: a method and clinical survey. Clin Allergy. 1977;7(3):235-43.

35. Davis BE, Simonson SK, Blais CM, Cockcroft DW. Methacholine challenge testing: a novel method for measuring PD $_{20}$. Chest. 2017;152(6):1251-7.

36. Coates AL, Wanger J, Cockcroft DW, Culver BH, Bronchoprovocation Testing Task Force. ERS technical standard on bronchial challenge testing: general considerations and performance of methacholine challenge tests. Eur Respir J. 2017;49(5):1601526. https://doi.org/10.1183/13993 003.01526-2016.

37. Coates AL, Leung K, Dell SD. Developing alternative delivery systems for methacholine challenge tests. J Aerosol Med Pulm Drug Deliv. 2014;27(1):66-70.

38. Blais CM, Cockcroft DW, Veilleux J, Boulay ME, Boulet LP, Gauvreau GM et al. Methacholine challenge: comparison of airway responsiveness produced by a vibrating mesh nebulizer versus a jet nebulizer. J Aerosol Med Pulm Drug Deliv. 2018;31(2):88-93.

39. American Thoracic Society, European Respiratory Society. ATS/ERS recommendations for standardized procedures for the online and offline measurement of exhaled lower respiratory nitric oxide and nasal nitric oxide, 2005. Am J Respir Crit Care Med. 2005;171(8):912-30.

40. Crapo RO, Casaburi R, Coates AL, Enright PL, Hankinson JL, Irvin CG, et al. Guidelines for methacholine and exercise challenge testing-1999. Am J Respir Crit Care Med. 2000;161(1):309-29.

41. Kirby JG, Hargreave FE, Gleich GJ, O’Byrne PM. Bronchoalveolar cell profiles of asthmatic and nonasthmatic subjects. Am Rev Respir Dis. 1987;136(2):379-83.

42. Wardlaw AJ, Dunnette S, Gleich GJ, Collins JV, Kay AB. Eosinophils and mast cells in bronchoalveolar lavage in subjects with mild asthma. Relationship to bronchial hyperreactivity. Am Rev Respir Dis. 1988;137(1):62-9.

43. Van Den Berge M, Meijer RJ, Kerstjens HA, de Reus DM, Koëter GH, Kauffman HF, et al. PC(20) adenosine 5'-monophosphate is more closely associated with airway inflammation in asthma than PC(20) methacholine. Am J Respir Crit Care Med. 2001;163(7):1546-50.

44. Choi SH, Kim DK, Yu J, Yoo Y, Koh YY. Bronchial responsiveness to methacholine and adenosine $5^{\prime}$-monophosphate in young children with asthma: their relationship with blood eosinophils and serum eosinophil cationic protein. Allergy. 2007;62(10):1119-24.

45. Polosa R, Renaud L, Cacciola R, Prosperini G, Crimi N, Djukanovic $R$. Sputum eosinophilia is more closely associated with airway responsiveness to bradykinin than methacholine in asthma. Eur Respir J. 1998;12(3):551-6.

46. Porsbjerg C, Brannan JD, Anderson SD, Backer V. Relationship between airway responsiveness to mannitol and to methacholine and markers of airway inflammation, peak flow variability and quality of life in asthma patients. Clin Exp Allergy. 2008;38(1):43-50.

47. Sverrild A, Bergqvist A, Bainse KJ, Porsbjerg C, Andersson CK, Thomsen $\mathrm{SF}$, et al. Airway responsiveness to mannitol in asthma is associated with chymase-positive mast cells and eosinophilic airway inflammation. Clin Exp Allergy. 2016;46(2):288-97.

48. Holgate ST, Hardy C, Robinson C, Agius RM, Howarth PH. The mast cell as a primary effector cell in the pathogenesis of asthma. J Allergy Clin Immunol. 1986;77(2):274-82.

49. Benckhuijsen J, van den Bos JW, van Velzen E, de Bruijn R, Aalbers R. Differences in the effect of allergen avoidance on bronchial hyperresponsiveness as measured by methacholine, adenosine $5^{\prime}$-monophosphate, and exercise in asthmatic children. Pediatr Pulmonol. 1996;22(3):147-53.

50. van Velzen E, van den Bos JW, Benckhuijsen JA, van Essel T, de Bruijn R, Aalbers R. Effect of allergen avoidance at high altitude on direct and indirect bronchial hyperresponsiveness and markers of inflammation in children with allergic asthma. Thorax. 1996;51(6):582-4.

51. van den Berge M, Kerstjens HA, Meijer RJ, de Reus DM, Koëter GH, Kauffman HF, et al. Corticosteroid-induced improvement in the PC20 of adenosine monophosphate is more closely associated with reduction in airway inflammation than improvement in the PC20 of methacholine. Am J Respir Crit Care Med. 2001;164(7):1127-32.

52. Prosperini G, Rajakulasingam K, Cacciola RR, Spicuzza L, Rorke S, Holgate ST, et al. Changes in sputum counts and airway hyperresponsiveness after budesonide: monitoring anti-inflammatory response on the basis of surrogate markers of airway inflammation. J Allergy Clin Imunol. 2002;110(6):855-61.

53. Brannan JD, Koskela H, Anderson SD, Chan HK. Budesonide reduces sensitivity and reactivity to inhaled mannitol in asthmatic subjects. Respirology. 2002;7(1):37-44.

54. Leuppi JD, Salome CM, Jenkins CR, Anderson SD, Xuan W, Marks GB, et al. Predictive markers of asthma exacerbation during stepwise dose reduction of inhaled corticosteroids. Am J Respir Crit Care Med. 2001;163(2):406-12.

55. Sont JK, Willems LN, Bel EH, van Krieken JH, Vandenbroucke JP, Sterk PJ. Clinical control and histopathologic outcome of asthma when using airway hyperresponsiveness as an additional guide to longterm treatment. The AMPUL Study Group. Am J Respir Crit Care Med. 1999;159(4 Pt 1):1043-51. 
56. Brannan JD, Koskela H, Anderson SD. Monitoring asthma therapy using indirect bronchial provocation tests. Clin Respir J. 2007;1(1):3-15.

57. Scichilone N, Kapsali T, Permutt S, Togias A. Deep inspiration-induced bronchoprotection is stronger than bronchodilation. Am J Respir Crit Care Med. 2000;162(3 Pt 1):910-6.

58. Brusasco V, Crimi E, Barisione G, Spanevello A, Rodarte JR, Pellegrino R. Airway responsiveness to methacholine: effects of deep inhalations and airway inflammation. J Appl Physiol (1985). 1999;87(2):567-73.

59. Slats AM, Janssen $K$, van Schadewijk $A$, van der Plas DT, Schot $R$, van den Aardweg JG, et al. Bronchial inflammation and airway responses to deep inspiration in asthma and chronic obstructive pulmonary disease. Am J Respir Crit Care Med. 2007;176(2):121-8.

60. Allen ND, Davis BE, Cockcroft DW. Correlation between airway inflammation and loss of deep-inhalation bronchoprotection in asthma. Ann Allergy Asthma Immunol. 2008;101(4):413-8.

61. Milanese M, Peroni D, Costella S, Aralla R, Loiacono A, Barp C, et al. Improved bronchodilator effect of deep inhalation after allergen avoidance in asthmatic children. J Allergy Clin Immunol. 2004;114(3):505-11.

62. Slats AM, Sont JK, van Klink RH, Bel EH, Sterk PJ. Improvement in bronchodilation following deep inspiration after a course of high-dose oral prednisone in asthma. Chest. 2006;130(1):58-65.
63. Prieto L, Ferrer A, Domenech J, Pérez-Francés C. Effect of challenge method on sensitivity, reactivity, and maximal response to methacholine. Ann Allergy Asthma Immunol. 2006;97(2):175-81.

64. Prieto L, Lopez V, Llusar R, Rojas R, Marin J. Differences in the response to methacholine between the tidal breathing and dosimeter methods: influence of the dose of bronchoconstrictor agent delivered to the mouth. Chest. 2008;134(4):699-703.

65. Cockcroft D, Davis B. Direct and indirect challenges in the clinical assessment of asthma. Ann Allergy Asthma Immunol. 2009;103(5):363-9.

66. Cockcroft DW, Hargreave FE. Airway hyperresponsiveness: relevance of random population data to clinical usefulness. Am Rev Respir Dis. 1990;142(3):497-500.

\section{Publisher's Note}

Springer Nature remains neutral with regard to jurisdictional claims in published maps and institutional affiliations.
Ready to submit your research? Choose BMC and benefit from:

- fast, convenient online submission

- thorough peer review by experienced researchers in your field

- rapid publication on acceptance

- support for research data, including large and complex data types

- gold Open Access which fosters wider collaboration and increased citations

- maximum visibility for your research: over $100 \mathrm{M}$ website views per year

At BMC, research is always in progress.

Learn more biomedcentral.com/submissions 